G. M. Kogut ${ }^{1}$, orcid.org/0000-0002-4780-7448, A. P. Oliinyk ${ }^{1}$, orcid.org/0000-0003-1031-7207, M. O. Karpash', orcid.org/0000-0002-4223-3828, A. M. Klyun ${ }^{2}$, orcid.org/0000-0003-3338-6811
1 - Ivano-Frankivsk National Technical University of Oil and Gas, Ivano-Frankivsk, Ukraine, e-mail: gmkogut@gmail.com 2 - "UA Transmission System Operator" Ltd, Kyiv, Ukraine

\title{
STATEMENT OF OPTIMIZATION TASKS FOR THE PROCESS OF DEVELOPING NORMATIVE DOCUMENTS FOR GAS INFRASTRUCTURE
}

Purpose. To establish and formulate optimization tasks in elaborating strategies for developing normative documents that identify the work performance at gas infrastructure facilities and the effectiveness of these measures in the pre-emergency and emergency situations.

Methodology. To develop the necessary regulatory support for the operation of natural gas transportation and distribution operators, the study presents a mathematical formalization of the optimization problems selection and probability estimate for the identification of strategies for developing new documents that will allow standardizing the basic parameters of trouble-free operation.

Findings. The factors that affect the safe operation of the gas transmission and gas distribution network, and cause emergencies, were identified and argued in the article. An experiential mathematical formalization for the process of developing normative documents was carried out; theoretically-justified optimization procedure based on a probabilistic optimization criterion and under conditions of incomplete definiteness was performed.

Originality. The research originality is in the new approach to scientific justification for the elaboration of strategies for normative document development in the gas industry.

Practical value. The results of the study allow establishing a scientifically based basis for the further development of the standardization system for gas infrastructure facilities in the context of EU policy priorities regarding safe, sustainable and affordable energy. The mathematical apparatus can be used by specialists of natural gas transportation and distribution companies to elaborate strategies and road maps for the development of gas transmission and gas distribution systems, respectively.

Keywords: regulatory documents, reliability, optimization, gas supply, standards

Introduction. In accordance with the Law of Ukraine "On the Natural Gas Market" [1], which provides for the implementation of a number of acts of Energy community legislation in the energy sector regarding the general rules of the national natural gas market, conditions to access the networks and the implementation of measures to ensure the security of natural gas supplies, all subjects, noted in the law, should carry out a number of organizational and technical measures that will be aimed at ensuring the technical safety of gas networks and gas installations, technical reliability of gas supply systems and technical compatibility with European gas networks. A significant number of these measures are concentrated in the field of standardization. However, practice shows that there is a variety of problems regarding the regulatory provision of such measures, mainly due to the fact that the organizational, technical and technological methods of Ukrainian gas networks operation differ significantly from similar European ones. In addition, the confidentiality of information on the causes of accidents and pre-emergency situations does not allow analysing the practical data on the development of scientifically-based foundations of standardization considering the activities of gas infrastructure operators to ensure safe and reliable gas supply.

Literature review. The problems concerning the adaptation of Ukrainian gas transmission system operation with the requirements of the EU were elaborated by Ginzburg M., Klyun A., Karpash M., Trebulova I., et al. As for the issues of organizing the operation of gas distribution companies, some resources, published by Halyuk L., Harmatyuk A., Horal L., Hrubyak S., Klyuva A., Eremenko A., Klymenko S., Petrenko U., Ryschuk L., Savva A., Struck N., et. at., cover the problems of a more economic nature (investments, strategic planning, cost analysis). The problems of ensuring the safety and

(C) Kogut G. M., Oliinyk A. P., Karpash M. O., Klyun A. M., 2020 reliability of the operation of pipeline systems from the point of view of natural gas losses during transportation, where the tasks of developing and optimizing the methods of operation and maintenance for improving the technology of pipeline transmission of natural gas were mainly solved, were considered in the publications of Honcharuk M., Kaptsov I., Seredyuk M., Sheludchenko V., Yakovlev E. However, the systemic problems of the regulatory support of gas network operators activities have not been solved in the context of the requirements of the EU Third Energy package from the view of gas supply safety and reliability. So, today there is a necessity for a detailed coverage of the methodological adaptation of existing regulatory documents with EU requirements and the development of mechanisms for planning, development and implementation of new regulatory documents (RD), which would sufficiently regulate the safe and reliable operation of Ukrainian gas market operators.

Unsolved aspects of the problem. Currently, the requirements of the existing legislation expect gas infrastructure operators to develop long-term plans for the development of gas networks, which must take into account the criteria for safe operation of the system, its technical condition, the value of operation specific costs, economic efficiency of investment activities. Considering all these factors, it is obvious that to regulate the safe and reliable operation of the entire system it is necessary to develop new regulations that contain rules of general and repeated use, guidelines or characteristics [2], which will allow achieving the optimal degree of order in the field of transportation and distribution of natural gas. At the same time, the issue of ensuring sustainable development [3] of natural gas transmission and distribution networks remains unresolved, taking into account the provisions on reducing production and technological losses caused by natural gas leaks during accidents. The current national normative documents in the gas infrastructure do not contain the provisions of sus- 
tainable development, and as for international and European normative documents, these standards contain only a partial provision on the environmental impact caused by emergency situations on gas pipeline sections. Accordingly, gas infrastructure operators need to implement additional measures to organize the design, construction, operation, maintenance and repair of gas infrastructure, as well as to measure the consumption of natural gas, determine its quality, and all these require them to get a detailed understanding of all technological processes, and specify the qualitative criteria and factors that will affect the processes in terms of secure gas supply. Only after obtaining the initial data, the standardization service of operators can elaborate the reasoned strategies for the development and implementation of regulations that will contain common rules to regulate the mitigation, prevention, and procedures order for pre-emergency situations or accidents, resulting in safe and reliable operation of gas pipeline systems in accordance with the requirements of current European and Ukrainian legislation.

Purpose. The article deals with the problem of regulatory support of Ukrainian gas infrastructure, namely its two key subdivisions - operators of transmission and distribution of natural gas, considering the context of the European single energy market formation in compliance with the principles of gas supply security and reliability. Accordingly, the main task of the article is to figure out and to set the optimization procedures to determine strategies for the development of normative documents that determine the operation of gas infrastructure and influence the effectiveness of measures during pre-emergency situations or accidents. Considering the primary task of the article, the following goals were defined:

- to identify and justify the factors that influence the safe operation of gas supply systems and cause pre-emergency situations or accidents;

- to carry out experimental mathematical formalization of the process for development of normative documents, regulating the operation of gas networks;

- to theoretically substantiate the optimization procedure on the basis of the probabilistic optimization criterion and within the conditions of incomplete certainty.

Methods. To conduct the study, the authors formalized the factors influencing the safe and reliable operation of natural gas transmission and distribution systems, identified the main tasks and methods to maintain the gas networks in sufficient safety and reliability described the most-common causes of pre-emergency situations and accidents, arising in gas distribution and gas transmission infrastructure objects. To formalize the process of normative documents development by applying the appropriate strategies, the optimization tasks of choosing the best strategy through the application of the methodology of the theory of games with nature and applying the expert method for identification of necessary criteria are formed and substantiated.

Results. 1. Current problems of gas pipelines operation. Safety and reliability of natural gas transmission and distribution systems is one of the critical priorities of national energy security. Therefore, natural gas transmission and distribution operators face the task of improving the regulatory framework for their core activities through the development and implementation of new approaches, methods and scenarios, taking into account the risks that may affect the safety of natural gas supplying the future.

First of all, it is important to take into account the factors that characterize the quality of pipelines, including the underground ones as well. In particular, in [4], it is noted that gas network operators must take into account the conditions of the pipe metal, methods for estimating the parameters that characterize the operational and limit states of the gas pipelines, technical requirements for reliability, durability and service life; safety factor, management of technological processes.

In order to achieve the required level of Ukrainian gas pipeline system safety (here, the authors assume high, medi- um and low pressure gas pipelines), firstly, it is necessary to minimize the impact of pre-emergency and accident modes of the system, and accordingly, it is necessary to take into account all factors that directly influence the arising of emergence situations.

According to the published research data [5], there is an increase in the number of emergencies at gas distribution system facilities caused by various factors. This increase is often caused not only due to the design branching of the entire system, but also due to the large number of components installed in the system, which are used to maintain the proper functioning of the system. However, the complexity of managing the system itself is also due to the fact that a large part of gas distribution network is placed underground in densely populated areas, as well as various emergencies can be caused by a combination of negative factors (corrosion, various stresses and others), which finally decrease the gas pipeline system resilience.

Actually, emergency situations in the process of technical operation of gas distribution networks are determined by the following factors that can be divided into two groups:

1) technical factors (aging of fixed assets, exhaustion of regulatory and warranty terms of equipment operation; complexity and change of conditions of gas distribution system construction and maintenance; complexity of preventive maintenance and repairs; variety in design and manufacturing; facility failures);

2) organizational and economic factors (access of third parties to the protection zones of gas distribution system, unauthorized work, negligence, vandalism, technology related and natural factors, heterogeneity of natural, social and economic conditions).

Therefore, in order to maintain the appropriate level of safety and reliability at gas distribution network facilities, it is regulated:

1) to conduct periodic inspection and control of the technical condition of gas pipelines and facilities related;

2) to perform well-timed actions of repair and maintenance works;

3 ) to provide the necessary modernization and renovation of gas pipelines and out-moded equipment;

4) to carry out systematic control of gas pipeline protection zones and site situation;

5) to provide well-timed prevention and responsive elimination of accidents and emergencies of man-made and natural nature, with simultaneous minimization of their consequences;

6) to prevent the environmental pollution properly;

7) to plan, development and implementation of actions on localization and elimination of emergencies and accidents.

Unfortunately, due to the confidentiality of information that, in the event of dissemination, may pose a threat to the national security of the state, there is a lack of factual data in Ukraine on the causes that have led to emergencies. Therefore, at present there are no official statistics on the causes and consequences of industrial, economic or environmental nature in Ukraine, which would allow providing a more detailed description of the issue of accidents at medium and low pressure gas networks.

Only some rare facts may be obtained after analysing the available information of the State Emergency Service of Ukraine on registered emergencies. So, when considering year 2019, the following information [6] was published in the media:

1. On January 3, 2019, as a result of a car collision, two gas pipelines of high pressure $159 \mathrm{~mm}$ and low pressure $76 \mathrm{~mm}$ were damaged).

2. On June 21, 2019, there was damage (flute crack) at the section of the high-pressure underground gas pipeline "Komarno-Pukenychi" with a diameter of $700 \mathrm{~mm}$, the facility belongs to the branch division of the gas transmission system operator of Ukraine "Western Region". 
3. On June 22, 2019, in Lviv region near the village of Piatnychany, Stryi district, depressurization took place with subsequent combustion on the gas pipeline $(\mathrm{d}-700 \mathrm{~mm})$, belonging to the Main Gas Pipelines Department "Prykarpattransgaz".

4. On November 5, 2019, a gas pipeline with a diameter of $90 \mathrm{~mm}$ was damaged in Kropyvnytskyi during excavation works.

Mostly, according to natural gas distribution companies' information, accidents or emergencies occur due to:

1) leaks of domestic gas pipelines due to the destruction of street or house networks;

2) unsatisfactory condition of gas networks (worn gas pipelines);

3) improper operation of gas equipment (explosions of gas-air mixture);

4) defects in gas pipelines (defects in welded joints; cracks in welded joints; defects in pipes during the manufacturing process, pipeline sagging);

5) corrosion damage to gas pipelines (caused by insulation damages or insulation poor performance);

6) gas pipelines damage during earthworks, damages caused by vehicles, other mechanical damages.

An important aspect for assessing the consequences of emergencies is the calculation of the number of residents who could potentially use gas networks and the probabilistic assessment of possible natural gas leaks during a gas pipeline accident and the actual assessment of the threat class by vulnerability. The importance of such an analysis is to update the system operators' response plans to pre-emergency and emergency situations with a possible list of corrective actions to prevent the spread of an abnormal situation or the effective elimination of existing consequences. But no less relevant is the prediction of such situations that can result in the loss of safe operation of the system and cause a cascade failure [7].

As for the facilities of the main gas pipelines, after analysing the occurrence of abnormal and emergency situations during 2000-2018, it is possible to identify the main causes and factors that affect the reliability and safety of the gas transmission system of Ukraine, as well as to explore the methods to improve the regulatory framework with the simultaneous reducing of the probability of occurrence of these factors.

According to the results of the published resources [8] and [9] analysis, it was determined that accidents and emergency situations at the main gas pipelines can occur for the following reasons:

1. Rupture of the pipeline due to defects in the pipe during the manufacturing process (pipe product manufacturers' not meeting the requirements of standards and specifications, as well as insufficient control by the factory-manufacture for product quality).

2. Accidents due to interference of third parties in the operation of the pipeline during excavation works in the protection zone (non-compliance with the requirements of technical conditions and normative regulations on health safety, no agreement with the owner of the gas pipeline concerning the technical design while performing the works, and so on).

3. Occurrence of an emergency situation caused by the corrosion destruction of the gas pipeline (due to the significant age of the gas transmission system of Ukraine).

4. Occurrence of emergency situations during repair works on the facilities of main gas pipelines.

5. Destruction of the gas pipeline due to stress-corrosion destruction of the pipe.

6. Other factors.

Accidents that occur during the transportation and supply of natural gas also have significant economic consequences. After all, any emergence situation in the system causes interruptions in gas transportation and increases the risk of explosions. That is why it is necessary to provide the well-timed determination of the operational condition of gas pipelines, which may precede the potential occurrence of pre-emergency or emergency situations [5].

Accidents that occur on gas pipelines have significant environmental consequences due to the thermal effects of fires and due to the actual leakage of natural gas. When natural gas is in the pipeline, the risks to the environment are minimal. However, accidents of various environmental origins result in large volumes of natural gas by the time gas supply to the emergency pipeline is cut off. It is known that natural gas contains up to $98 \%$ of methane. And methane itself has a negative impact that is twenty times greater than the same volume of carbon dioxide [10]. Accordingly, the increase in the number of methane leaks caused by accidents on gas networks leads to an increase in the negative impact on the environment. Therefore, it is appropriate to state that the analysis of emergency situations on gas pipelines should be an integral part of methane leakage reduction programs, which should be adopted and implemented by gas network operators.

Today, these issues are partially included in the development programs of gas transmission and distribution network operators, the results of which are designed to ensure the sustainable operation of the entire system, bringing into line with modern standards of environmental performance and overall efficiency of mutually beneficial cooperation in context of integration into the European market. However, the effective implementation of the action plan is impossible without the development of an optimal methodology that will achieve the projected performance with minimal costs and promote reliable operation of networks. However, in an attempt to reduce the impact on the environment, the balance of the entire system must be maintained, as there is a situation now, where reliable energy systems are destroyed under the guise of fighting for the environment, and the planned targets for reducing harmful emissions are not achieved [11].

The above-stated factors show a largely related dependency to the regulatory framework, especially standards. Though, it is equally important to consider the availability of a comprehensive technical base that puts together all the activities related to the operation of gas transmission and distribution systems' facilities; availability of access of all engineering, technical and operating personnel of the gas system operator to standards and norms; unconditional fulfilment of the requirements prescribed in the norms and standards by all personnel who perform activities on maintenance, operation and repair of gas system facilities.

That is, in the presence of appropriate norms and standards that regulate the quality of equipment used at gas transmission and distribution systems' facilities, strict compliance with the requirements of standards and norms during inspection, maintenance, repair, scheduled activities, the operators make it possible to reduce the occurrence of emergency situations or accidents and ensure reliable and safe operation of the gas transmission and distribution network.

According to the analysis of the regulatory and technical base of natural gas transmission and distribution operators, it is possible to determine the most commonly used standards, the use of which has the greatest impact on the operation of the gas transmission and distribution systems of Ukraine. Considering this, the continuous work with these standards, constant improving of the works methodology and ensuring the unconditional fulfilment of requirements, stated in the standards, it is possible to ensure an appropriate level of reliability and security of gas supply in Ukraine.

Given the above provisions, there is a need to develop strategies to optimize the development of normative documents to ensure trouble-free operation of the gas pipeline system of Ukraine.

2. Development of a mechanism for optimizing the system of normative documents. 2.1. Mathematical formalization of the process. The standard provisions of the theory of games with nature are used to solve the problem of optimizing the process 
for standards developing [12]. Game theory is a theory of mathematical models for making optimal decisions within the conflict presence. The task of game theory is to develop recommendations for the rational behaviour of game participants. [13]. The advantage of game theory is the ability to expand the concept of optimality, including, for example, a compromise solution that meets various needs of the game. The theory is implemented by constructing appropriate matrices and selecting optimal strategies. Under the optimal strategy a specific-purpose strategy is understood, which, provided repeated occurrence, allows the player to get the maximum possible average win.

Let one of the parties (the developer of the strategy) have three strategies:

1. Strategy $Q_{1}$, which is based on the development of the most standard normative documents, allowing the operator to anticipate actions in case of the most typical emergency situations, the cost of its development and implementation is $S_{1}$.

2. Strategy $Q_{2}$, which provides for actions at the moment of a larger number of emergency situations, taking into account the specifics of the system, its cost is $S_{2}$.

3. Strategy $Q_{3}$, which is the broadest by its areas of application strategy, providing a response to the occurrence of virtually all emergency situations, its cost is $S_{3}$.

Obviously, $S_{1}<S_{2}<S_{3}$.

Each of these strategies allows the operator to respond to certain emergency or pre-emergency situations that occur with probability or frequency $p_{j, j}=1, \ldots, N$. In addition, according to the analysis of statistical data, matrix $A$ is possible to be built, which characterizes the presumable losses in the event of a situation $B_{j}$ occurrence with the probability pj. In the general case, the specified matrix will look like this

$$
A=\left[\begin{array}{lllll}
a_{11} & a_{12} & a_{13} & \cdots & a_{1 n} \\
a_{21} & a_{22} & a_{23} & \cdots & a_{2 n} \\
a 3_{1} & a_{32} & a_{33} & \cdots & a_{3 n}
\end{array}\right],
$$

critical element aij is going to be expressed as follows

$$
a_{i j}=A_{j}\left(1-q_{i j}\right),
$$

where the values have the following meanings: $A_{j}$ - statistical information on the losses suffered by the industry in the event of an emergency situation $B_{j}$ with probability $p_{j} ; q_{i j}$ - the probability of the strategy $S_{i}$ "triggering" during the occurrence of event $B_{j}$ with $p_{j}$ probability.

Estimation $A_{j}$ in formulae (2) is established on the basis of analysis and processing of statistical data on the consequences of emergency situations (as a rule, losses of economic, social or environmental nature are taken into account). It is seen that for each column of the matrix $A$ the value of $A_{j}$ is constant the losses values vary depending on the strategy of $S_{i}$ standards selection process.

Thus, the general task can be set as follows: the operator should find the optimal strategy for the development of normative documents $S_{i}$, relative to the cost for standards development and implementation and the ability to respond to emergencies, based on the known "game matrix $A$ " (1) with components, which will be expressed by (2).

\subsection{Calculation of the basic parameters of the task. Pj prob-} ability estimation. Two possible cases are considered:

1. Probabilities $P_{j}$ are selected from statistical data on the occurrence of emergency situations - in many published resources $[14,15]$ statistical data on the causes of accidents at the facilities of natural gas market operators are given in the form of diagrams, tables, and so on - for example, the reason for the gas pipeline failure can be: corrosion, design errors, construction defects, violations of operating modes, and others. If such information is available, the percentage of reasons for failure is selected $P_{j}$.

2. Probabilities are selected by the method of expert evaluation. The defined parameters provide for the coopera- tion of designers, contractors and gas distribution network operators. The method of expert evaluation provides an opportunity to combine experience, which allows taking into account all the most important factors influencing the value of risks associated with emergencies in gas distribution networks.

In order to conduct the optimization procedure, a group of experts sets the priority of the causes of abnormal situations $B_{j}$ by estimating the largest of the set $\{1, \ldots, N\}$, where $N$ is the number of reasons under consideration or negative impact factors. Thus, for each situation $B_{j}$ the $M$-number of estimates is set, where $M$ corresponds to the number of experts

$$
B_{j}=\left\{b_{j m}\right\}, \quad m=1, \ldots, M .
$$

In such a case the following equation is used

$$
P_{j}=\frac{\sum_{m=1}^{M} b_{j m}}{\sum_{j=1}^{N} \sum_{m=1}^{M} b_{j m}}
$$

where the denominator shows the total sum of estimates, and the numerator - the sum of estimates of the situation $B_{j}$. A question arises as to the degree of confidence in the opinion of experts and their consistency. For this purpose, the Kendell concordance coefficient is calculated: $N$ - the number of indicators (situations $B_{j}$ ); $M$ - the number of experts; $r_{i j}$ - a rank of the $i^{\text {th }}$ indicator for all experts (numerator in (3)).

Then the concordance coefficient $\mathrm{W}$ is determined by the following equation [16]

$$
W=\frac{12}{M^{2}\left(N^{3}-N\right)} \sum_{i=1}^{N}\left(\left[d_{i}-\bar{d}\right]^{2}\right),
$$

where

$$
\bar{d}=\frac{M(N+1)}{2} .
$$

If $W>0.75-$ the opinion of experts is well agreed, it should be trusted (obviously, $0 \leq \mathrm{W} \leq 1$ ).

Calculations of $\boldsymbol{q}_{i j}$ in (2). These probabilities characterize the degree of "triggering" of the $S_{i}$ strategy on the situation $B_{j}$ that has occured, and is determined on the basis of statistical data on the degree of elaboration of the question of reaction to $B_{j}$ in the $S_{i}$ strategy. It is obvious that $0 \leq q_{i j} \leq 1$, where, $q_{i j}=0$, in case when the strategy concerning the development of normative documents $S_{i}$ does not state anything about the response to $B_{j}$. In fact, $q_{i j}$ can also be determined by the above method of expert evaluation.

Structure (2) can be explained as follows: $a_{i j}=A_{j}\left(1-q_{i j}\right)$ means that the greater the value $\left(1-q_{i j}\right)$ - the degree of failure of $S_{i}$ in this specific case - is, the greater the losses from the situation $B_{j}$ will be. Thus, the formal description of the task is complete.

2.3. Optimization procedure. In the case described in this article, it is advisable to use the probabilistic optimization criterion, which for the following given game situation

$$
\begin{aligned}
& \begin{array}{lllll}
P_{1} & P_{2} & \ldots & \ldots & P_{N} ;
\end{array} \\
& Q_{1}\left[\begin{array}{lllll}
a_{11} & a_{12} & \ldots & \ldots & a_{1 n}
\end{array}\right] S_{1} \\
& \begin{array}{llllll}
Q_{2} & a_{21} & a_{22} & \ldots & \ldots & a_{2 n}
\end{array} S_{2}, \\
& Q_{3}\left[\begin{array}{lllll}
a_{31} & a_{32} & \ldots & \ldots & a_{3 n}
\end{array}\right] S_{3}
\end{aligned}
$$

is stated as follows: it is necessary to choose the specific situation out of $Q_{1}, Q_{2}, Q_{3}$, for which the following criterion is fulfilled

$$
\min i\left\{S_{i}+\sum_{j=1}^{N} a_{j i} P_{j}\right\} .
$$


According to this given criterion, the optimal $Q_{i}$ strategy out of three evaluated is selected, for which the minimum is the sum of the costs, $S_{i}$, of normative documents development and implementation and the expected losses value in the event of each of the emergency situation $B_{j}$, is minimum.

According to the theoretical provisions of games with nature [16], optimization procedures can be performed using other approaches.

Laplace uncertainty principle: it is assumed that all probabilities $P_{j}$ are equal

$$
P_{1}=P_{2} \ldots=P_{N}=\frac{1}{N}
$$

then, considering the equation (5) criterion (4) is given as follows

$$
\min _{i}\left\{S_{i}+\frac{1}{N} \sum_{j=1}^{N} a_{i j}\right\} .
$$

Modified Hurwitz criterion

$$
\min _{i}\left\{S_{i}+\min _{i}\left\{\frac{\max _{j} a_{i j}+\min _{j} a_{i j}}{2}\right\}\right\},
$$

considering which the risk parameters are $\lambda=\frac{1}{2}, 0 \leq \lambda \leq 1$, and when $\lambda=0-$ the risk is of maximum value, $\lambda=1-$ the risk is of minimum value; and the criterion (6) remains in the following expression

$$
\min _{i}\left\{S_{i}+\min _{i}\left\{\lambda \max _{j} a_{i j}+(1-\lambda) \min a_{i j}\right\}\right\} .
$$

\section{Conclusions.}

1. Issues concerning the safe and reliable transmission and distribution of natural gas are regulated by the requirements of both current legislation and normative documents of different levels of adoption. At the same time, a proper understanding and detailed study of issues related to maintaining the proper level of operation of gas transmission and distribution systems will allow the operator to organize more active work on standardization in this area, as the results obtained will eventually create an updated regulatory framework for promoting and maintaining of trouble-free operation of gas infrastructure systems. This task is specifically urgent in the conditions of reforming the natural gas market of Ukraine. In addition, the updating of gas infrastructure regulations should be implemented on the principles of generalization of current international and European practice, taking into account the components of national methods of production processes organization, as failures in proper implementation of current world practice of gas infrastructure causes significant difficulties for well-timed and planned transition to the implementation of EU requirements for gas infrastructure.

2. Given that the process of developing a modern regulatory framework for operators of transmission and distribution of natural gas does not have an upgraded scientifically based approach, for this reason it is important to provide a mathematical apparatus aimed at optimization of the regulatory document development. Consequently, it is proposed to use standard provisions of the theory of game with nature through matrices and optimal strategies charting. Further improvement of the proposed methodology will allow developing an approach to solving the problems of updating regulatory documents, including the provisions of sustainable development of gas infrastructure. Accordingly, the implementation of the proposed optimization procedure will take place in practical methods and algorithms of optimized sequence of development of new regulations to ensure efficient operation of gas pipelines.
3. Areas of further research to optimize the development of new regulations in accordance with the proposed strategies are related to the numerical implementation of this approach and the development of a method of practical assessment of $A_{j} ; q_{i j}$; $P_{j} ; N ; M ; S_{i} ; i=1 \ldots 3 ; j=1 \ldots N$, The results of the proposed procedure will allow studying the possibilities of optimizing the structure and characteristics of the regulatory system, providing experimental justification of the application for the optimized system of normative documents and calculating the possible economic efficiency of new algorithms, as well as identifying proposals for improving the other factors of economic, social and environmental nature.

\section{References.}

1. Gov.UA (n.d.). Law of Ukraine No. 329-19 of 09.04.2015 "On natural gas market". Retrieved from http://zakon5.rada. gov.ua/laws/show /329-19/page.

2. Gov.UA (n.d.). Law of Ukraine No. 1315-VII of 05.06.2014 "On standardization". Retrieved from http://zakon0.rada.gov. ua/laws/show/1315-18/page.

3. Korol, S. V. (2018). Imperatives of development of oil-gas complex enterprises in Ukraine. Skhidna Yevropa: ekonomika, biznes ta upravlinnia, (14), 194-198.

4. Askari, M., Aliofkhazraei, M., \& Afroukhteh, S. (2019). A Comprehensive Review on Internal Corrosion and Cracking of Oil and Gas Pipelines. Journal of Natural Gas Science and Engineering, 102971. https://doi.org/10.1016/j.jngse.2019.102971. 5. Bianchini, A., Guzzini, A., Pellegrini, M., \& Saccani, C. (2018). Natural gas distribution system: A statistical analysis of accidents data. International Journal of Pressure Vessels and Piping. https://doi.org/10.1016/j.ijpvp.2018.09.003.

6. The State Emergency Service of Ukraine (2019) Retrieved from http://www.dsns.gov.ua.

7. Kryvenko, H., \& Vozniak, L. (2018). Research of consequences of emergency situations at the industrial pipelines. Scientific Bulletin of Ivano-Frankivsk National Technical University of Oil and Gas, 2(45), 41-47.

8. Kuliczkowska, E. (2015). Analysis of defects with a proposal of the method of establishing structural failure probability categories for concrete sewers. Archives of Civil and Mechanical Engineering, 15(4), 1078-1084. https://doi.org/10.1016/j. acme.2015.02.002.

9. Khrutba, V. O., Vaihanh, H.O., \& Stehnii, O. M. (2017). Analysis of environmental hazards during main pipeline operation and maintenance. Ekolohichna bezpeka, (2), 75-82.

10. Nuclear Energy Agency, Organization for Economic Cooperation and Development (2019). The costs of decarbonization: System Costs with High Shares of Nuclear and Renewables. Retrieved from https://www.oecd-nea.org/ndd/ pubs/2019/7299-system-costs.pdf.

11. Balcombe, P., Speirs, J.F., Brandon, N.P., \& Hawkes, A. D. (2018). Methane emissions: choosing the right climate metric and time horizon. Environmental Science: Processes \& Impacts. https://doi.org/10.1039/c8em00414e.

12. Krupa, T., \& Ostrowska, T. (2016). Hierarchical DecisionMaking Problems - Modeling and Solutions. Foundations and Management, 8(1), 311-324. https://doi.org/10.1515/fman2016-0024.

13. Neogy, S. K., Bapat, R. B., \& Dubey, D. (2018). Mathematical Programming and Game Theory. Springer.

14. Bianchini, A., Guzzini, A., Pellegrini, M., \& Saccani, C. (2018). Natural gas distribution system: A statistical analysis of accidents data. International Journal of Pressure Vessels and Piping. https://doi.org/10.1016/j.ijpvp.2018.09.003.

15. Marcogaz (2017). Report on European Gas Safety, Gas Distribution (EGAS B). Retrieved from https://www.marcogaz. org/a p p / d ownload / $7719246263 /$ S TAT - 26 EGAS+B+Report+2006 2015.pdf?t=152958870.

16. Kochenderfer, M.J. (2015). Decision Making Under Uncertainty: Theory and Application. Massachusetts Institute of Thechnology: The MIT Press. ISBN-13: 978-0262029254. 


\section{Постановка оптимізаційних задач для процесу розроблення нормативних документів для газової інфраструктури}

\author{
Г. М. Когум ${ }^{1}$, А. П. Олійник 1 , М. О. Карпаш 1 , \\ А. М. Клюнь ${ }^{2}$
}

1 - Івано-Франківський національний технічний університет нафти і газу, м. Івано-Франківськ, Україна, е-таil: gmkogut@gmail.com

2 - ТОВ «Оператор газотранспортної системи України», м. Київ, Україна

Мета. Формування й постановка оптимізаційних задач для визначення стратегій розроблення нормативних документів, що визначають проведення робіт на об'єктах газової інфраструктури та ефективність цих заходів за умов передаварійних і аварійних ситуацій.

Методика. Задля розроблення необхідного нормативного забезпечення роботи операторів транспортування й розподілу природного газу в роботі представлена математична формалізація вибору оптимізаційних задач й оцінка ймовірностей для формування стратегій розроблення нових документів, шо дозволять унормувати основні параметри безаварійної роботи.

Результати. У статті визначені та аргументовані чинники, що впливають на безпечний режим експлуатування газотранспортної й газорозподільної мереж, та спричиняють виникнення аварійних ситуацій; проведена експериментальна математична формалізація процесу розроблення нормативних документів; теоретично обгрунтована оптимізаційна процедура на основі ймовірнісного критерію оптимізації та в умовах неповної визначеності.

Наукова новизна. Полягає в новому підході до наукового обгрунтування розроблення стратегії створення нормативних документів у газовій галузі.

Практична значимість. Результати проведеного дослідження дозволяють створити науково-обгрунтовані основи для подальшого розвитку системи стандартизації об'єктів газової інфраструктури в контексті пріоритетів політики СС шодо безпечної, сталої й доступної енергії. Математичний апарат може застосовуватися фахівцями компаній із транспортування й розподілу природного газу для розроблення стратегій і дорожніх карт розвитку газотранспортної й газорозподільної систем відповідно.

Ключові слова: нормативні документи, безпека, надійність, оптимізація, постачання газу, стандарти

\section{Постановка оптимизационных задач для процесса разработки нормативных документов для газовой инфраструктуры}

\author{
Г. М. Когут ${ }^{1}$, А. П. Олийнык ${ }^{1}$, М. О. Карпаш ${ }^{1}$, \\ А. М. Клюнь ${ }^{2}$
}

1 - Ивано-Франковский национальный технический университет нефти и газа, г. Ивано-Франковск, Украина, e-mail: gmkogut@gmail.com

2 - ООО «Оператор газотранспортной системы Украины», г. Киев, Украина

Цель. Формирование и постановка оптимизационных задач для определения стратегий разработки нормативных документов, определяющих проведение работ на объектах газовой инфраструктуры и эффективность этих мероприятий в условиях предаварийных и аварийных ситуаций.

Методика. Для разработки необходимого нормативного обеспечения работы операторов транспортировки и распределения природного газа в работе представлена математическая формализация выбора оптимизационных задач и оценка вероятностей для формирования стратегий разработки новых документов, которые позволят нормировать основные параметры безаварийной работы.

Результаты. В статье определены и аргументированы факторы, которые влияют на безопасный режим эксплуатации газотранспортной и газораспределительной сети, и вызывают возникновение аварийных ситуаций. Проведена экспериментальная математическая формализация процесса разработки нормативных документов, теоретически обоснована оптимизационная процедура на основе вероятностного критерия оптимизации и в условиях неполной определенности.

Научная новизна. Заключается в новом подходе к научному обоснованию разработки стратегии создания нормативных документов в газовой отрасли.

Практическая значимость. Результаты проведенного исследования позволяют создать научно обоснованные основы для дальнейшего развития системы стандартизации объектов газовой инфраструктуры в контексте приоритетов политики ЕС в отношении безопасной, устойчивой и доступной энергии. Математический аппарат может применяться специалистами компаний по транспортировке и распределению природного газа для разработки стратегий и дорожных карт развития газотранспортной и газораспределительной систем соответственно.

Ключевые слова: нормативные документы, безопасность, надежность, оптимизация, поставки газа, стандарты

Recommended for publication by Ye. I. Kryzhanivsky, Doctor of Technical Sciences. The manuscript was submitted 27.05.19. 